\title{
Hubungan Minat Membaca dengan Prestasi Belajar Mata Pelajaran IPS Kelas III SD Karanggayam
}

\author{
Nur Ari Marlina \\ Prodi PGMI, FAI Universitas Alma Ata \\ Martalia Ardiyaningrum \\ Prodi PGMI, FAI Universitas Alma ata dan martalia.ardiyaningrum@almaata.ac.id
}

\begin{abstract}
Abstrak
Penelitian ini bertujuan untuk mengetahui tingkat minat membaca siswa kelas III dan hubungan antara minat membaca dengan prestasi belajar siswa pada mata pelajaran IPS kelas III SD Karanggayam baik secara parsial maupun secara keseluruhan. Penelitian ini menggunakan pendekatan kuantitatif dengan teknik korelasional. Populasi dalam penelitian ini adalah seluruh siswa kelas III SD Karanggayam tahun pelajaran 2018/2019 dan sampel penelitian ini adalah siswa kelas III dengan jumlah 21 siswa. Instrumen penelitian yang digunakan yaitu angket untuk mengukur minat membaca, sedangkan untuk prestasi belajarnya didapat dari nilai ulangan siswa pada mata pelajaran IPS. Analisis data menggunakan korelasi person dengan program aplikasi komputer SPSS Versi 20 for Windows. Hasil penelitian menunjukkan bahwa: 1) minat membaca siswa SD Karanggayam masuk dalam kategori cukup baik dilihat dari hasil tabulasi angket yaitu sebesar 76\%; 2) Koefisien Pearson menunjukan hasil nilai signifikansi sebesar 0,581 dengan taraf signifikan 5\% atau dapat dikatakan bahwa tidak terdapat hubungan yang signifikan antara minat membaca dengan prestasi belajar IPS siswa SD Karanggayam.
\end{abstract}

Kata Kunci: minat membaca, prestasi belajar, IPS

\begin{abstract}
This study aims to determine the level of interest in reading of grade III students and the relationship between reading interest and student achievement in social studies in grade III of SD Karanggayam either partially or as a whole. This study used a quantitative approach with correlational techniques. The population in this study were all class III students of SD Karanggayam in the 2018/2019 academic year and the sample of this study was grade III students with a total of 21 students. The research instrument used was a questionnaire to measure reading interest, while the learning achievement was obtained from students' test scores in the social studies subject. Data analysis used person correlation with SPSS Version 20 for Windows computer application program. The results showed that: 1) the students' reading interest of SD Karanggayam was in the good enough category as seen from the tabulation results of the questionnaire, which showed 76\%; 2) The Pearson coefficient shows a significance value of 0.581 with a significant level of 5\% or it can be said that there is no significant relationship between reading interest and social studies achievement of students of SD Karanggayam.
\end{abstract}

Keywords: reading interest, learning achievement, social studies 


\section{PENDAHULUAN}

Kemampuan literasi merupakan kemampuan yang dapat dikembangkan sejak dini, anak dapat memahami maupun melakukan aktifitas berdasarkan informasi yang diperoleh 1. Kemampuan ini dapat dikembangkan melalui kebiasaan membaca dan menulis. Dalam lingkungan keluarga, orang tua dapat membiasakan untuk mengenalkan kebiasaan baca melalui kegiatan membaca cerita berupa dongeng, kisah nabi, atau bacaan yang lainnya. Dengan demikian, kegiatan membaca menjadi bagian dalam kehidupan sehari-hari anak, sehingga budaya membaca dapat terbentuk dalam diri anak. Sumber bacaan tersebut dapat diperoleh dengan membeli buku bacaan (berbentuk hardcopy) ataupun mengakses secara online melalui internet. Saat ini sudah tidak ada kendala dalam memperoleh sumber bacaan bagi orang tua, karena berbagai cerita dapat diakses secara digital. Kapan dan dimanapun orang tua berada dapat mengunduh cerita/dongeng sebagai sumber bacaan bagi putra-putrinya.

Pada kenyataannya tidak semua orang tua memiliki kesempatan atau melaksanakan kegiatan rutin membaca cerita/dongeng untuk putra-putrinya. Hal ini diduga menjadi penyebab siswa memiliki minat baca yang masih rendah di tingkat sekolah dasar. Hasil dari PIRLS (Progress in Internasional Reading Literacy Study) untuk sekolah dasar tahun 2006 yang dilaksanakan oleh International Association for Evaluation of Educational Achievement (IEA) menunjukkah bahwa rata-rata kemampuan membaca siswa sekolah dasar untuk tujuan literasi berada di urutan 41 dari 45 negara yang mengikuti penilaian ini. ${ }^{2}$ Hasil ini tentunya memprihatinkan bagi dunia pendidikan, karena menunjukkan bahwa dalam hal melek aksara Negara Indonesia masih terbelakang.1l

Fakta lain diperoleh dari hasil wawancara

1 Yasir Riady, 'LITERASI INFORMASI SEJAK DINI: PENGETAHUAN BARU BAGI ANAK USIA DINI', JIV, $2013<$ https://doi.org/10.21009/jiv.0802.10>.

2 Michael O Martin, Ina V S Mullis, and Ann M Kennedy, PIRLS 2006 Technical Report, TIMMS \& PIRLS International Study Center, 2007. awal dengan siswa kelas III SD Karanggayam, menunjukkan bahwa siswa lebih menyukai buku komik dibandingkan buku mata pelajaran. Selain itu, siswa lebih banyak menghabiskan waktunya dengan bermain games. Hal ini disebabkan karena dalam buku komik terdapat banyak gambar menarik dibandingkan buku pelajaran. Hasil observasi di SD Karanggayam pada tahun 2019 menunjukkan bahwa perpustakaan sekolah kurang dimanfaatkan dengan baik oleh siswa. Dari 139 siswa hanya terdapat 60 siswa perbulannya yang mengunjungi perpustakaan sekolah. Hal ini dapat dimaknai bahwa bahwa hanya 50\% siswa SD Karanggayam mengunjungi perpustakaan dengan frekuensi satu bulan sekali. Selain itu, jam buka perpustakaan masih tidak teratur, dikarenakan penjaga perpustakaan juga merupakan guru batik. Oleh karena itu dalam pembagian jam buka perpustakaan tidaklah setiap hari.

Dinas Perpustakaan dan Kearsipan Daerah Kota Metro ${ }^{3}$ menyebutkan bahwa berdasarkan data dari UNESCO, minat baca di Indonesia hanya sebesar $0,01 \%(0,01$ persen $)$. Data ini memberikan gambaran bahwa dari 10.000 penduduk di Indonesia, hanya 1 orang yang memiliki minat baca. Padahal dengan membaca akan dapat membuka cakrawala dunia dan menambah pemahaman wawasan yang luas mengenai ilmu pengetahuan. Untuk generasi millennial, budaya literasi ini merupakan salah satu senjata untuk mengurangi disinformasi seperti hoal dan hate speech beredar di masyarakat ${ }^{4}$. Namun saat ini minat untuk membaca masih sangat rendah, lebih khusus

3 Melinda Indriyani, 'Upaya Untuk Meningkatkan Minat Literasi Terhadap Masyarakat Agar Dapat Membangun Masa Depan Yang Diinginkan', Dinas Perpustakaan Dan Kearsipan Daerah Kota Metro, 2018 $<$ https://dispusarda-metro.com/index.php?page=detail_ artikel\&\&id=111\#.XyE3PzUxXIU> [accessed 29 July 2020].

4 Anggi Pratiwi and Eflinnida Nurul Komaril Asyarotin, 'Implementasi Literasi Budaya Dan Kewargaan Sebagai Solusi Disinformasi Pada Generasi Millennial Di Indonesia', Jurnal Kajian Informasi \& Perpustakaan, 7.1 (2019), 65-80 <https://doi.org/10.24198/jkip. v7i1.20066>. 
lagi dalam pembelajaran IPS (Ilmu Pengetahuan Sosial) di sekolah yang menuntut siswa memahami sejarah yang begitu banyaknya, sehingga siswa mau tidak mau harus membaca sejarah tersebut untuk memahami materi IPS.

Nilai Ujian Akhir Semester siswa kelas III SD Karanggayam pada materi IPS menunjukkan hasil yang belum maksimal. Sebanyak $65 \%$ siswa memperoleh nilai di bawah KKM (kriteria ketuntasan minimal), berarti bahwa hanya $35 \%$ siswa yang telah tuntas KKM, dengan KKM yang ditetapkan adalah 75 . Hal ini diduga karena metode guru dalam mengajar mata pelajaran IPS masih didominasi dengan ceramah, tanya jawab, dan penugasan. Aktifitas siswa mengunjungi perpustakaan untuk mencari referensi materi pelajaran IPS belum dioptimalkan. Selain itu siswa juga kurang antusias pada bacaan, sehingga sedikit sekali anak yang mau membaca di saat mereka diberi tugas oleh guru untuk memahami bacaan. Hal ini diduga menjadi penyebab siswa kurang antusias dalam memanfaatkan waktu istirahat untuk mengunjungi perpustakaan. Sejalan dengan pendapat Magdalena ${ }^{5}$ yaitu kurangnya minat baca siswa sekolah dasar disebabkan kurangnya kemauan dari siswa sendiri untuk terlibat dalam kegiatan membaca, serta guru belum melibatkan siswa secara internsif dalam kegiatan membaca buku saat pembelajaran ataupun sebelum pembelajaran.

Perlu adanya kajian lebih lanjut hubungan antara minat baca siswa dengan prestasi belajar siswa (khususnya) dalam materi IPS. Oleh karena itu dalam penelitian ini ingin menganalisis: 1) tingkat minat membaca siswa kelas III pada materi IPS di SD Karanggayam, 2) hubungan antara minat membaca siswa dengan prestasi belajar siswa kelas III pada materi IPS di SD Karanggayam.

\section{Minat Membaca}

Minat membaca dapat diartikan sebagai

5 Magdalena Elendiana, 'Upaya Meningkatkan Minat Baca Siswa Sekolah Dasar', Junal Pendidikan Dan Konseling, 1.2 (2020), 63-68<https://doi.org/https://doi. org/10.31004/jpdk.v1i2.572>. keinginan yang kuat diiringi usaha dari seseorang guna melaksanakan kegiatan membaca dengan dilandasi kesadaran dari diri sendiri ${ }^{6}$. Dalam pembelajaran di SD, pengertian tersebut memberikan penekanan bahwa keinginan membaca muncul dari diri siswa sendiri tanpa adanya paksaan dari pihak lain. Guna membangun minat baca ini, perlu pembiasaan bagi siswa untuk membaca berbagai sumber belajar baik yang tersedia di perpustakaan sekolah maupun tempat lainnya. Adapun aspek yang mempengaruhi minat membaca diantaranya adalah 1) kesenangan terhadap kegiatan membaca; 2) frekuensi waktu yang diluangkan untuk membaca; 3 ) banyaknya buku yang telah dibaca; dan 4) kesadaran terhadap manfaat membaca ${ }^{7}$.

Aspek pertama yang perlu dibangun adalah kesenangan terhadap kegiatan membaca, hal ini dapat dilakukan oleh guru dengan memberikan motivasi berupa penjelasan manfaat membaca bagi setiap siswa. Frekuensi waktu membaca dan banyaknya buku yang dibaca juga menunjukkan minat membaca dari peserta didik. Semakin sering seseorang meluangkan waktu untuk membaca, menunjukkan bahwa tingkat minat membacanya semakin tinggi.

Terdapat faktor yang dapat menghambat minat membaca bagi siswa di lingkungan sekolah ${ }^{8}$ diantaranya adalah-1) kurangnya teladan oleh orang tua atau guru, 2) kurangnya bahan bacaan yang bermutu untuk memenuhi keinginan membaca anak, dan 3) tidak adanya pendidikan dan pembinaan membaca di sekolah. Berdasarkan faktor-faktor penghambat tersebut, tampak bahwa pembiasaan membaca di sekolah merupakan salah satu faktor penting dalam membangun budaya membaca di sekolah.

6 F Rahim, Pengajaran Membaca Di Sekolah Dasar, Bumi Aksara, 2007; Ajip Rosidi, Pembinaan Minat Baca: Bahasa Dan Sastera, ed. by Adriyani Kamsyach (Bandung, 2016).

7 Henry Guntur Tarigan, Membaca Sebagai Suatu Keterampilan Berbahasa (Ed.Revisi), Revisi (Bandung: CV Angkasa, 2015).

8 Hernowo, Mengikat Makna Update : Membaca Dan Menulis Yang Memberdayakan, ed. by Budhyastuti (Bandung: Kaifa, 2009). 
Pembiasaan ini dapat dilakukan melalui pemberian contoh oleh guru, pemberian tugas membaca kepada siswa, dan melalui program literasi lainnya yang dikembangkan oleh pihak sekolah.

\section{Prestasi Belajar}

Prestasi belajar diartikan sebagai hasil capaian pengetahuan dan ketrampilan siswa melalui proses pembelajaran baik di dalam maupun di di luar kelas ${ }^{9}$. Asmara menambahkan bahwa pencapaian hasil belajar tersebut dapat diukur melalui skor pengetahuan maupun ketrampilan yang menunjukkan tingkat keberhasilan siswa dalam mengikuti proses pembelajaran.

Sejalan dengan pendapat tersebut, Djaali dan Muljojo menyebutkan bahwa prestasi belajar merupakan tingkat perkembangan atau kemajuan yang telah dicapai siswa setelah mengikuti proses pembelajaran dalam jangka waktu tertentu ${ }^{10}$. Berdasarkan beberapa pendapat ahli di atas, prestasi belajar dapat dimaknai sebagai pencapaian pengetahuan, sikap, maupun ketrampilan siswa yang dapat diukur menggunakan skor penilaian.

\section{METODE PENELITIAN}

Jenis penelitian yang digunakan yaitu penelitian kuantitatif. Penelitian kuantitatif merupakan penelitian yang digunakan untuk meneliti populasi dan sampel tertentu, teknik pengambilan sampel dilakukan secara total atau seluruh siswa yang diteliti, pengumpulan data dengan menggunakan instrument berupa angket, dan analisis datanya bersifat statistik dengan angka dan bantuan SPSS versi 20 dengan tujuan menguji hipotesis yang telah ditetapkan. Penelitian korelasi bertujuan untuk mendeteksi sejauh mana variabel pada suatu faktor berhubungan dengan variabel pada satu atau lebih faktor lain berdasarkan koefisien

\footnotetext{
$9 \quad$ Saifudin Azwar, Tes Prestasi, Fungsi Dan Pengembangan Pengukuran Prestasi Belajar, Pustaka Pelajar, 2015; Asmara, Prestasi Belajar (Bandung: Remaja Rosdakarya, 2009).

10 Djaali and Pudji Muljojo, Pengukuran Dalam Bidang Pendidikan, PT. Grasindo, 2008.
}

korelasi ${ }^{11}$.

Sample penelitian ini adalah siswa kelas III di SD Karanggayam sebanyak 21 siswa. Untuk populasi penelitian ini adalah seluruh siswa di SD Karanggayam tahun pelajaran 2018/2019 yang berjumlah 139 siswa.

Instrumen yang digunakan untuk mengumpulkan data penelitian adalah lembar observasi, angket, dan dokumen SD Karanggayam. Observasi digunakan untuk mengamati jalannya kegiatan pembelajaran IPS di kelas III SD Karanggayam. Angket digunakan untuk menghimpun data persepsi minat membaca pada pembelajaran IPS. Dokumentasi merupakan teknik untuk mengumpulkan data hasil ulangan IPS di kelas III SD Karanggayam.

Data persepsi minat membaca siswa merupakan data primer yang langsung dihimpun melalui angket yang dikembangkan dalam penelitian ini dengan jumlah butir adalah 25 . Sedangkan, data prestasi belajar IPS merupakan data sekunder yang diperoleh peneliti dari data ulangan harian IPS yang telah dilaksanakan oleh guru kelas III.

Kisi-kisi Angket minat Membaca tersaji sebagai berikut:

Tabel 1. Kisi-Kisi Angket Minat Membaca

\begin{tabular}{llcc}
\hline \multirow{2}{*}{ Variabel } & \multicolumn{1}{c}{ Indikator } & \multicolumn{2}{c}{ Nomor Butir } \\
\cline { 2 - 4 } & & Positif & Negatif \\
\hline $\begin{array}{l}\text { Minat } \\
\text { Membaca }\end{array}$ & $\begin{array}{l}\text { Kesenangan } \\
\text { membaca }\end{array}$ & 4 & 4 \\
\cline { 2 - 4 } & $\begin{array}{l}\text { Kesadaran man- } \\
\text { faat membaca }\end{array}$ & 8 & 5 \\
\cline { 2 - 4 } & $\begin{array}{l}\text { Frekuensi mem- } \\
\text { baca }\end{array}$ & 3 & 1 \\
\hline \multicolumn{2}{c}{ Jumlah butir } & 15 & 10 \\
\hline
\end{tabular}

Teknik analisis data yang digunakan dalam penelitian ini adalah 1) tabel kategori minat membaca, dan 2) uji korelasi pearson dengan bantuan program SPSS versi 20 for Windows. Adapun tabel kategori minat membaca mengikuti kategori di bawah ini ${ }^{12}$

\footnotetext{
${ }^{11}$ (Sugiyono 2015:14)

12 (Saifuddin Azwar, 2012:109)
} 
Tabel 2. Kategori Minat Membaca

\begin{tabular}{ccc}
\hline No & Rentang & Kategori \\
\hline 1 & $\mathrm{X} \geq(\mathrm{M}+1,0 \mathrm{SD})$ & Baik \\
\hline 2 & $(\mathrm{M}-1,0 \mathrm{SD})<\mathrm{X}<(\mathrm{M}+1,0 \mathrm{SD})$ & Cukup \\
\hline 3 & $\mathrm{X} \leq(\mathrm{M}-1,0 \mathrm{SD})$ & Kurang \\
\hline
\end{tabular}

Keterangan:Rerata dan standar deviasi ideal diperoleh dengan rumus :

$\mathrm{Mi}=1 / 2($ skor tertinggi + skor terendah $)$

$\mathrm{SDi}=1 / 6($ skor tertinggi + skor terendah $)$

Hasil korelasi antara variable minat membaca dengan prestasi belajar mata pelajaran IPS akan dikonsultasikan terhadap interpretasi koefisien korelasi yang dikemukakan oleh Sugiyono ${ }^{1314}$ sebagai berikut:

Tabel 3. Pedoman Interpretasi Koefisien Korelasi

\begin{tabular}{cc}
\hline Interval Koefisien & Tingkat Hubungan \\
\hline $0,00-0,199$ & Sangat rendah \\
\hline $0,20-0,399$ & Rendah \\
\hline $0,40-0,599$ & Sedang \\
\hline $0,60-0,799$ & Kuat \\
\hline $0,80-1,00$ & Sangat kuat \\
\hline
\end{tabular}

Untuk penelitian kualitatif seperti penelitian tindakan kelas, studi kasus, dan lain-lain, perlu ditambahkan kehadiran peneliti, subyek penelitian, informan yang ikut membantu beserta cara-cara menggali datadata penelitian, lokasi dan lama penelitian serta uraian mengenai pengecekan keabsahan hasil penelitian.

\section{HASIL DAN PEMBAHASAN}

Minat Membaca Kelas III SD Karanggayam

Pengukuran minat membaca kelas III pada mata pelajaran IPS terdiri dari tiga indikator yaitu kesenangan dalam membaca, kesadaran manfaat membaca, dan frekuensi membaca. Analisis berdasarkan statistik diskriptif terhadap masing-masing indikator angket minat membaca siswa kelas III SD Karanggayam dapat disajikan

\footnotetext{
13 (Sugiyono 2015)

14 Sugiyono, Metode Penelitian Pendidikan Pendekatan Kualitatif, Kuantitatif, $R \& D$.
}

pada table di bawah ini:

Tabel 4. Statistik Deskriptif Minat Membaca Siswa Kelas III

\begin{tabular}{lccccc}
\hline & Ban- & \multicolumn{4}{c}{ Statistik Deskriptif } \\
\cline { 3 - 6 } $\begin{array}{c}\text { Indika- } \\
\text { yak }\end{array}$ & $\begin{array}{c}\text { Butir } \\
\text { Builai }\end{array}$ & $\begin{array}{c}\text { Nini- } \\
\text { mum }\end{array}$ & $\begin{array}{c}\text { Naksi- } \\
\text { Maksi- } \\
\text { mum }\end{array}$ & Mean & $\begin{array}{c}\text { Stan- } \\
\text { dar } \\
\text { Deviasi }\end{array}$ \\
\hline $\begin{array}{l}\text { Kesenan- } \\
\text { gan mem- }\end{array}$ & 8 & 13 & 29 & 22,19 & 3,789 \\
baca & & & & & \\
\hline $\begin{array}{l}\text { Kes- } \\
\text { adaran } \\
\text { manfaat } \\
\text { membaca }\end{array}$ & 13 & 26 & 48 & 36,28 & 5,090 \\
\hline $\begin{array}{l}\text { Frekuensi } \\
\text { membaca }\end{array}$ & 4 & 8 & 15 & 11,14 & 1,740 \\
\hline
\end{tabular}

Data statistic deskriptif minat membaca diperoleh dari sampel yang berjumlah 21 siswa. Angket minat ini disusun dengan 4 (empat) alternatif pilihan jawaban yaitu 1) Sangat Sesuai (SS), 2) Sesuai (S), 3) Tidak Sesuai (TS), dan 4) Sangat Tidak Sesuai (STS). Secara berturutturut skor yang diberikan jika pernyataan angket positif adalah 4, 3, 2, dan 1, Sedangkan untuk pernyaat angket negative maka secara berturutturut skor yang diberikan adalah 1, 2, 3, dan 4 . Berdasarkan nilai mean setiap indikator nampak bahwa nilai Mean dibagi dengan banyak butir menunjukkan nilai yang relative sama yaitu 2,7; hal ini menunjukkan bahwa peserta didik dalam menjawab angket minat membaca ini memberikan jawaban dominan antara angka 2 dan 3. Hal ini mengarah pada masih perlu peningkatan minat membaca pada siswa SD khususnya siswa kelas III. Berikut hasil angket minat secara keseluruhan (mencakup 3 indikator).

Tabel 5. Kategorisasi Minat Membaca

\begin{tabular}{ccccc}
\hline No & $\begin{array}{c}\text { Rentang } \\
\text { Skor }\end{array}$ & $\begin{array}{c}\text { Frekuensi } \\
\text { kuensi }\end{array}$ & $\begin{array}{c}\text { Persen- } \\
\text { tase }\end{array}$ & Kategori \\
\hline 1 & $\mathrm{X} \geq 78$ & 3 & $14 \%$ & Baik \\
\hline 2 & $61<\mathrm{X}<78$ & 16 & $76 \%$ & Cukup \\
\hline 3 & $\mathrm{X} \leq 61$ & 2 & $10 \%$ & Kurang \\
\hline & Total & 21 & $100 \%$ & \\
\hline
\end{tabular}


Tabel di atas menunjukkan bahwa secara keseluruhan, minat membaca siswa kelas III SD Karanggayam masuk dalam kategori cukup. Hasil angket minat membaca untuk setiap indikator juga dikonsultasikan pada table kategori minat membaca ${ }^{15}$ sebagai berikut:

Tabel. 6. Kategorisasi Indikator Kesenangan Membaca

\begin{tabular}{ccccc}
\hline \multirow{2}{*}{ No } & $\begin{array}{c}\text { Rentang } \\
\text { Skor }\end{array}$ & \multicolumn{2}{c}{ Frekuensi } & \\
\cline { 3 - 4 } & $\begin{array}{c}\text { Fre- } \\
\text { kuensi }\end{array}$ & $\begin{array}{c}\text { Persen- } \\
\text { tase }\end{array}$ & Kategori \\
\hline 1 & $X \geq 24$ & 4 & $19 \%$ & Baik \\
\hline 2 & $16<X<24$ & 16 & $76 \%$ & Cukup \\
\hline 3 & $X \leq 16$ & 1 & $5 \%$ & Kurang \\
\hline & Total & 21 & $100 \%$ & \\
\hline
\end{tabular}

Tabel di atas menunjukkan bahwa sebanyak 76\% siswa masuk dalam kategori cukup senang dalam membaca. Hanya terdapat $19 \%$ siswa yang memiliki kesenangan membaca dalam kategori baik. Terdapat berbagai faktor yang dapat menjadi penyebab masih kurangnya rasa senang membaca bagi siswa, diantaranya faktor lingkungan keluarga dan faktor kurikulum/pendidikan sekolah ${ }^{16}$. Faktor lingkungan keluarga memiliki peranan penting dalam menumbuhkan rasa senang dalam membaca, dengan orang tua membiasakan putra/ putrinya membaca sedari kecil akan membangun kebiasaan membaca ${ }^{17}$. Kebiasaan ini akan menjadi bagian dari kehidupan sehari-hari anak, sehingga rasa senang akan menjauhkan dari keterpaksaan membaca. Peran orang tua memang sangat penting dalam membangun rasa senang dalam membaca. Hal ini sejalan dengan

15 Saifuddin Azwar.

16 Tia Ulfa Amelia, 'FAKTOR-FAKTOR YANG MEMPENGARUHI MINAT BACA SISWA SD NEGERI 125 PEKANBARU', Primary: Jurnal Pendidikan Guru Sekolah Dasar, $2020<$ https://doi.org/10.33578/jpfkip. v9i1.7565>.

17 Wiyani Windrawati and others, 'Analisis Faktor Penghambat Belajar Membaca Permulaan Pada Siswa Kelas I SD Inpres 141 Matalamagi Kota Sorong', 2.1 (2020), 10-16; R.M. Arnold, Prijana, and Sukaesih, 'Potensi Membaca Buku Teks', Jurnal Kajian Informasi \& Perpustakaan, 2015. hasil penelitian Wiyani Windrawati, dkk yang mengemukakan bahwa budaya membaca harus diawali sedini mungkin melalui lingkungan keluarga sehingga lebih mudah menanamkan kebiasaan membaca yang baik ${ }^{18}$.

Faktor lain yang membangun rasa senang membaca adalah dukungan dari kurikulum/ pendidikan yang diberlakukan sekolah/ madrasarh. Selain lingkungan keluarga, lingkungan sekolah/madrasah juga dapat membangun rasa senang membaca. Kurikulum yang kurang tegas mencantumkan kegiatan membaca pada suatu bahan kajian, serta guru yang kurang memberikan motivasi siswa untuk membaca akan menjadi faktor penghambat dalam menumbuhkan rasa senang membaca bagi siswa ${ }^{19}$. Dua faktor ini merupakan faktor strategis yang dapat membangun rasa senang membaca dengan melihat sebagian besar waktu siswa dijalani di rumah dan di sekolah.

Tabel. 7. Kategorisasi Indikator Kesadaran Manfaat Membaca

\begin{tabular}{ccccc}
\hline \multirow{2}{*}{ No } & $\begin{array}{c}\text { Rentang } \\
\text { Skor }\end{array}$ & $\begin{array}{c}\text { Frekuensi } \\
\text { kuensi }\end{array}$ & $\begin{array}{c}\text { Persen- } \\
\text { tase }\end{array}$ & Kategori \\
\hline 1 & $\mathrm{X} \geq 39$ & 3 & $14 \%$ & Baik \\
\hline 2 & $26<\mathrm{X}<39$ & 17 & $81 \%$ & Cukup \\
\hline 3 & $\mathrm{X} \leq 26$ & 1 & $5 \%$ & Kurang \\
\hline & Total & 21 & $100 \%$ & \\
\hline
\end{tabular}

Hasil pada indikator kesadaran manfaat membaca tidak jauh berbeda dengan indikator kesenangan membaca, yaitu sebanyak $81 \%$ siswa masih dalam kategori cukup sadar manfaat membaca. Hal ini memberikan makna bahwa perlu upaya dalam meningkatkan pemahaman manfaat membaca kepada peserta didik. Upaya ini dapat dilakukan baik oleh pihak keluarga, sekolah, maupun masyarakat ${ }^{20}$. Melihat hasil yang dari table 5, maka perlu upaya baik dari keluarga, sekolah, maupun masyarakat untuk

\footnotetext{
18 Windrawati and others.

19 Amelia.

20 Windrawati and others; Arnold, Prijana, and Sukaesih; Amelia.
} 
membangun persepsi siswa tentang peran penting dari aktifitas membaca.

Keluarga sebagai lingkungan utama peserta didik, dalam membangun kesadaran manfaat membaca dapat dimulai dari orang tua. Orang tua dapat mendampingi peserta didik dalam kegiatan membaca dan memberikan pengertian pentingnya dari kegiatan membaca. Kegiatan yang dapat dilakukan oleh orang tua diantaranya adalah kegiatan membaca bersama dengan anak, kegiatan mendongeng di rumah secara bergantian, dan masih banyak kegiatan yagn dapat dilakukan olerh orang tua dengan anak dalam membangun kesadaran pentingnya membaca. Seperti yang disampaikan oleh Peran yang dapat diberikan oleh Tia Ulfa Amelia dalam jurnalnya ${ }^{21}$, bahwa semakin besar motivasi membaca yang diberikan oleh orang tua kepada anaknya, maka anak akan semakin giat dalam melakukan aktifitas membaca. Dengan kegiatan ini, anak akan semakin sadar akan pentingnya kegiatan membaca dalam memperluas pengetahuan mereka.

Tabel. 8. Kategorisasi Indikator Frekuensi Membaca

\begin{tabular}{ccccc}
\hline \multirow{2}{*}{ No } & $\begin{array}{c}\text { Rentang } \\
\text { Skor }\end{array}$ & \multicolumn{2}{c}{ Frekuensi } & \\
\cline { 3 - 4 } & $\begin{array}{c}\text { Fre- } \\
\text { kuensi }\end{array}$ & $\begin{array}{c}\text { Persen- } \\
\text { tase }\end{array}$ & Kategori \\
\hline 1 & $\mathrm{X} \geq 10$ & 13 & $62 \%$ & Baik \\
\hline 2 & $2<\mathrm{X}<10$ & 8 & $38 \%$ & Cukup \\
\hline 3 & $\mathrm{X} \leq 2$ & 0 & $0 \%$ & Kurang \\
\hline & Total & 21 & $100 \%$ & \\
\hline
\end{tabular}

Pada indikator frekuensi membaca menunjukkan hasil yang berbeda dengan indikator yang lainnya, yaitu sebanyak $62 \%$ siswa masuk dalam kategori baik untuk frekuensi membacanya, dan 38\% masuk dalam kategori cukup. Hal ini memberikan gambaran bahwa siswa kelas III telah meluangkan waktu untuk membaca. Hasil ini belum berbanding lurus $100 \%$ dengan hasil pada indikator kesenangan membaca. Pada indikator kesenangan membaca, persepsi siswa lebih dominan pada kategori

21 Amelia. cukup sedangkan pada indikator frekuensi membaca persepsi siswa lebih dominan pada kategori baik. Jika dua indikator ini dikaitkan, semakin siswa memiliki rasa senang terhadap kegiatan membaca maka frekuensi membaca juga akan semakin meningkat. Akan tetapi, dalam hasil kuesioner ini, frekuensi membaca sudah masuk dalam kategori baik tapi kesenangan membaca siswa masih dalam kategori cukup.

Beberapa hal yang menjadi penyebab terjadinya kondisi ini salah satunya adalah jenis motivasi membaca siswa. Seperti hasil penelitian dari Riyadi yang menyebutkan bahwa sebagian besar siswa melakukan aktifitas membaca karena terpaksa karena diminta oleh orang tua atau guru membaca ${ }^{22}$. Dalam hal ini motivasi untuk melakukan suatu aktifitas yaitu motivasi dari dalam diri sendiri dan motivasi dari eksternal (seperti dari guru maupun orang tua). Hal ini sejalan dengan pendapat Ajip Rosidi, bahwa minat membaca adalah suatu rasa lebih tertarik dan suka pada bahasa tulis (membaca) tanpa ada yang menyuruh dan dilakukan dengan kesadaran akan motivasi membaca dari dalam diri sendiri ${ }^{23}$.

Minat membaca ini akan terbangun saat kesenangan membaca telah muncul dari dalam diri seorang siswa. Hal yang perlu dibangun dalam diri siswa adalah rasa suka terhadap kegiatan membaca, dan dalam menumbuhkan rasa tersebut maka perlu stimulus dari lingkungan sekitarnya baik keluarga, sekolah, maupun masyarakat.

\section{Hubungan Minat Membaca Dan Prestasi Belajar IPS}

Prestasi belajar mata pelajaran IPS kelas III SD Karanggayan, yang diperoleh dari hasil ulangan harian ditunjukkan melalui diagram batang di bawah ini.

22 Riyadi Dwi Prasetya, 'Membangun Kesadaran Aktif Membaca Prestasi Dan Motivasi Belajar Siswa', 4.1 (2013), 26-38.

23 Rosidi. 


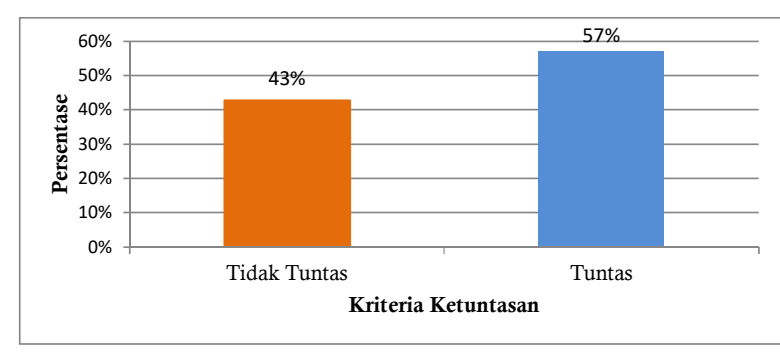

\section{Gambar 1. Hasil Ulangan Harian IPS Siswa kelas III}

Kriteria Ketuntasan Minimun (KKM) di kelas III SD Karanggayam adalah 75, sehingga siswa dengan nilai lebih dari atau sama dengan 75 akan dinyatakan tuntas. Artinya terdapat 43\% siswa kelas III pada ulangan harian IPS memperoleh nilai kurang dari 75. Data inilah yang akan diolah untuk memperoleh hubungan antara prestasi belajar dengan minat membaca siswa SD Karanggayam.

Untuk menentukan hubungan antara minat membaca siswa dengan prestasi belajar
IPS digunakan uji korelasi dengan Pearson Correlation. Sebelum uji korelasi dilakukan, terlebih dahulu dilakukan uji prasyarat yaitu uji normalitas dan uji linearitas. Pada uji normalitas digunakan Uji Kolmogorov-Smirnov $Z$, dengan nilai signifikansi 0,829. Karena nilai signifikansi lebih besar dari alpha $(0,829>0,05)$ maka data minat membaca memenuhi syarat normalitas. Sedangkan untuk nilai signifikan pada uji normalitas data prestasi belajar IPS adalah 0,135, maka data prestasi belajar IPS memenuhi syarat uji normalitas.

Uji syarat berikutnya adalah uji linearitas, yang mana hasil uji linearitas antara variable prestasi belajar IPS dengan Minat membaca menunjukkan angka signifikansi sebesar 0,738 yang berarti nilai ini lebih besar dari alpha $(0,05)$ sehingga memenuhi syarat linearitas. Setelah memenuhi uji prasyarat normalitas dan linearitas, maka uji korelasi dapat dilakukan.

Tabel 9. Korelasi Minat Membaca dengan Prestasi Belajar IPS

\begin{tabular}{llcc}
\hline Variabel & \multicolumn{1}{c}{ Variabel } & $\begin{array}{c}\text { Prestasi } \\
\text { Belajar }\end{array}$ & $\begin{array}{c}\text { Minat } \\
\text { Membaca }\end{array}$ \\
\hline \multirow{2}{*}{ Prestasi Belajar } & Pearson Correlation & 1 & 0,128 \\
\cline { 2 - 4 } & Sig. (2-tailed) & 21 & 0,581 \\
\cline { 2 - 4 } Minat Membaca & $\mathrm{N}$ & 0,128 & 21 \\
\cline { 2 - 4 } & Pearson Correlation & 0,581 & 1 \\
\cline { 2 - 4 } & Sig. (2-tailed) & 21 & 21 \\
\hline
\end{tabular}

Nilai signifikansi uji korelasi menggunakan rumus Pearson adalah 0,581 yang mana nilai ini lebih besar dari alpha $(0,05)$ yang berarti bahwa tidak ada hubungan yang signifikan antara minat membaca dengan prestasi belajar IPS siswa SD Karanggayam. Hasil koefisien korelasi dari table 8 menunjukkan nilai koefisien korelasi antara variable minat membaca dnegan presetasi belajar IPS adalah 0,128. Nilai ini jika konsultasikan terhadap table 3 (pedoman interpretasi koefisien korelasi) masuk dalam tingkat hubungan yagn sangat rendah. Dapat diartikan pula bahwa tidak ada hubungan antara prestasi belajar IPS dengan minat membaca.
Hasil korelasi ini, menunjukkan bahwa siswa yang memiliki prestasi belajar mata pelajaran IPS yang tinggi, belum tentu memiliki minat membaca yang tinggi pula. Begitu pula sebaliknya, siswa yang memiliki prestasi belajar mata pelajaran IPS yang rendah, belum tentu memiliki minat membaca yang rendah. Terdapat beberapa dugaan terhadap hasil penelitian ini, salah satunya adalah ruang lingkup materi tes prestasi belajar yang dikerjakan oleh siswa. Lingkup materi dalam mata pelajaran IPS terdiri dari 1) gejala lingkungan geografi, 2) masalah dan peristiwa social masyarakat, 3) sejarah, dan 
4) bidang ekonomi ${ }^{24}$.

Keempat ruang lingkup di atas tentu saja membutuhkan ketrampilan membaca untuk memahami materi tersebut. Tentu saja frekuensi membaca dari keempat materi tersebut berbedabeda, seperti materi sejarah membutuhkan frekuensi membaca lebih dibandingkan bidang ekonomi. Untuk bidang ekonomi, siswa akan lebih mudah memahami materi jika terlibat langsung dalam kegiatan ekonomi seperti di kantin sekolah/koperasi sekolah, atau di pasar. Pada tes prestasi belajar yang digunakan dalam penelitian ini adalah tes belajar pada materi: 1) mengenal lingkungan alam dan buatan, dan 2) memelihara lingkungan alam dan buatan di sekitar rumah. Karakteristik dari materi ini merujuk pada pembelajaran yang menekankan pada kegiatan pengamatan yang didukung dengan kegiatan membaca. Oleh karena itu dalam penelitian ini, hubungan antara variable minat membaca dengan prestasi belajar mata pelajaran IPS belum Nampak.

Untuk keempat ruang lingkup materi IPS tersebut, guru tetap harus membiasakan aktifitas membaca bagi peserta didiknya, karena tanpa membaca siswa akan mengalami kesulitan dalam memahami dan memecahkan masalah yang ada dalam mata pelajaran IPS tersebut. Materinya seperti apa, aktifitas membaca perlu dijadikan bagian dari pelajaran IPS karena akan membantu siswa dalam menumbuhkan rasa terbiasa membaca yang selanjutnya diharapkan dapat menjadi senang dalam membaca.

\section{KESIMPULAN}

Minat membaca siswa kelas III SD Karanggayam masuk dalam kategori cukup. Jika dilihat dari indikator minat membaca, indikator yang memberikan kontribusi dominan pada kategori baik adalah frekuensi membaca. Minat membaca siswa kelas III SD Karanggayam pada indikator frekuensi membaca masuk dalam kategori baik. Uji hipotesis korelasi antara

\footnotetext{
24 Sapriya, Pendidikan IPS Konsep Dan Pembelajaran, Pendidikan IPS Konsep Dan Pembelajaran (Bandung: Remaja Rosdakarya, 2009).
}

minat membaca dan prestasi belajar pada mata pelajaran IPS menunjukkan tidak terdapat hubungan antara minat membaca dan prestasi belajar pada mata pelajaran IPS. Hasil ini diduga berkaitan dengan materi yang diujikan pada tes mata pelajaran IPS, yaitu materi bidang ekonomi.

Untuk penelitian berikutnya, yang ingin melihat hubungan antara minat membaca dengan prestasi belajar diharapkan dapat menentukan materi yang menuntut ketrampilan membaca lebih besar, diantaranya materi sejarah atau masalah dan peristiwa social masyarakat. Pemilihan materi yang tepat ini diharapkan mampu menunjukkan hubungan antara minat membaca dengan prestasi belajar yang lebih signifikan. Selain itu, untuk pembelajaran IPS di SD hendaknya secara terus-menerus melibatkan aktifitas membaca baik membaca di lingkungan kelas, sekolah, maupun rumah. Dengan kegiatan membaca yang rutin ini akan menguatkan minat membaca peserta didik.

\section{DAFTAR PUSTAKA}

Amelia, Tia Ulfa, 'FAKTOR-FAKTOR YANG MEMPENGARUHI MINAT BACA SISWA SD NEGERI 125 PEKANBARU', Primary: Jurnal Pendidikan Guru Sekolah Dasar, $2020<$ https://doi.org/10.33578/ jpfkip.v9i1.7565>

Arnold, R.M., Prijana, and Sukaesih, 'Potensi Membaca Buku Teks', Jurnal Kajian Informasi \& Perpustakaan, 2015

Asmara, Prestasi Belajar (Bandung: Remaja Rosdakarya, 2009)

Azwar, Saifuddin, Penyusunan Skala Psikologi (Ed.2), Pustaka Pelajar, 2012

Azwar, Saifudin, Tes Prestasi, Fungsi Dan Pengembangan Pengukuran Prestasi Belajar, Pustaka Pelajar, 2015

Djaali, and Pudji Muljojo, Pengukuran Dalam Bidang Pendidikan, PT. Grasindo, 2008 Elendiana, Magdalena, 'Upaya Meningkatkan Minat Baca Siswa Sekolah Dasar', Junal Pendidikan Dan Konseling, 1.2 (2020), 63-68<https://doi.org/https://doi. org/10.31004/jpdk.v1i2.572>

LITERASI, Volume XII, No. 12021 
Hernowo, Mengikat Makna Update : Membaca Dan Menulis Yang Memberdayakan, ed. by Budhyastuti (Bandung: Kaifa, 2009)

Indriyani, Melinda, 'Upaya Untuk Meningkatkan Minat Literasi Terhadap Masyarakat Agar Dapat Membangun Masa Depan Yang Diinginkan', Dinas Perpustakaan Dan Kearsipan Daerah Kota Metro, 2018 $<$ https://dispusarda-metro.com/index. php?page $=$ detail_artikel\&\&id=111\#. XyE3PzUxXIU> [accessed 29 July 2020]

Martin, Michael O, Ina V S Mullis, and Ann M Kennedy, PIRLS 2006 Technical Report, TIMMS \& PIRLS International Study Center, 2007

Prasetya, Riyadi Dwi, 'Membangun Kesadaran Aktif Membaca Prestasi Dan Motivasi Belajar Siswa', 4.1 (2013), 26-38

Pratiwi, Anggi, and Eflinnida Nurul Komaril Asyarotin, 'Implementasi Literasi Budaya Dan Kewargaan Sebagai Solusi Disinformasi Pada Generasi Millennial Di Indonesia', Jurnal Kajian Informasi \& Perpustakaan, 7.1 (2019), 65-80<https:// doi.org/10.24198/jkip.v7i1.20066>

Rahim, F, Pengajaran Membaca Di Sekolah Dasar, Bumi Aksara, 2007
Riady, Yasir, 'LITERASI INFORMASI SEJAK DINI: PENGETAHUAN BARU BAGI ANAK USIA DINI', JIV, $2013<$ https:// doi.org/10.21009/jiv.0802.10>

Rosidi, Ajip, Pembinaan Minat Baca: Bahasa Dan Sastera, ed. by Adriyani Kamsyach (Bandung, 2016)

Sapriya, Pendidikan IPS Konsep Dan Pembelajaran, Pendidikan IPS Konsep Dan Pembelajaran (Bandung: Remaja Rosdakarya, 2009)

Sugiyono, Metode Penelitian Pendidikan Pendekatan Kualitatif, Kuantitatif, $R \&$ $D$ (Bandung: ALFABETA, 2015)

___ Metode Penelitian Pendidikan Pendekatan Kuantitatif, Kualitatif, Dan $R \& D$ (Bandung: ALFABETA, 2015)

Tarigan, Henry Guntur, Membaca Sebagai Suatu Keterampilan Berbahasa (Ed.Revisi), Revisi (Bandung: CV Angkasa, 2015)

Windrawati, Wiyani, Harun Gafur, Program Studi Pgsd, Universitas Pendidikan, and Muhammadiyah Sorong, 'Analisis Faktor Penghambat Belajar Membaca Permulaan Pada Siswa Kelas I SD Inpres 141 Matalamagi Kota Sorong', 2.1 (2020), $10-16$ 